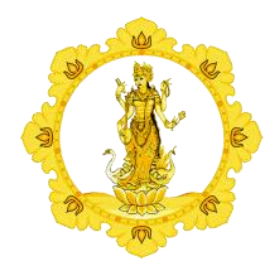

KALANGWAN

JURNAL PENDIDIKAN AGAMA, BAHASA DAN SASTRA

Vol. 11 No. 2 September 2021

\begin{tabular}{|c|c|c|}
\hline p-ISSN : 1979-634X & e-ISSN : 2686-0252 & http://ejournal.ihdn.ac.id/index.php/Kalangwan \\
\hline
\end{tabular}

\title{
STRATEGI GURU PADA PENINGKATAN KEMAMPUAN BERBICARA DALAM BAHASA BALI
}

\author{
Oleh : \\ Putu Eddy Purnomo Arta ${ }^{1)}$, Kadek Jayanthi Riva Prathiwi ${ }^{2)}$, I Kadek Ruminten ${ }^{3)}$ \\ 1)2)3) Universitas Hindu Negeri I Gusti Bagus Sugriwa Denpasar \\ E-mail: putueddy84@gmail.com ${ }^{1)}$, rivaprathiwiriva@gmail.com ${ }^{2}$, \\ rumintenkadek@ gmail.com ${ }^{3)}$
}

Diterima 22 Juli 2021, direvisi 13 Agustus 2021, diterbitkan 31 September 2021

\begin{abstract}
Abstrak
Penelitian ini meneliti tentang strategi guru pada peningkatan kemampuan berbicara dalam bahasa bali. Metode yang digunakan yaitu metode kualitatif dengan pendekatan deskriptif. Pemakaian bahasa daerah dalam kehidupan sehari-hari khususnya bahasa bali kian menurun karena kurangnya motivasi untuk belajar. Hal ini tercermin ketika berbicara menggunakan bahasa bali. Melihat fenomena tersebut, maka seorang guru memiliki peran penting dalam meningkatkan kemampuan berbicara siswa yang sesuai dengan anggahungguhing basa bali. Tujuan penelitian ini, yaitu untuk meningkatkan kemampuan berbicara siswa dalam bahasa bali. Melalui strategi pembelajaran yang tepat, guru diharapkan mampu meningkatkan keterampilan berbicara siswa, yang didukung oleh lingkungan keluarga. Factorfaktor yang mempengaruhi keterampilan siswa dalam berbicara menggunakan bahasa bali yaitu factor internal dan factor eksternal. Semoga dengan kolaborasi antara keluarga dan guru di sekolah dalam mendidik anak khususnya melatih kemampuan berbicara dalam bahasa bali, dapat melahirkan seorang anak yang mencintai budayanya sendiri, khususnya bahasa bali.
\end{abstract}

\section{Kata Kunci : Campur Kode, Sosiolinguistik, Identitas Bangsa}

\section{PENDAHULUAN}

\subsection{Konteks Penelitian}

Pendidikan merupakan suatu proses yang dilakukan secara sengaja diselenggarakan guna mengembangkan pengetahuan, keterampilan, dan keahlian. Salah satu masalah dalam pendidikan adalah rendahnya mutu pendidikan hal ini tercermin dalam hasil prestasi siswa. 
Masalah lainnya adalah guru masih menempatkan siswa sebagai objek bukan subjek didik. Pendidikan kita masih kurang dalam memberikan kesempatan bagi peserta didik dalam mengembangkan kemampuan berfikir ataupun mengembangkan keterampilannya. Menurut Undang-undang Sistem Pendidikan Nasional no. 20 Tahun 2003 Bab 1 Pasal 1 ayat 1, dijelaskan bahwa Pendidikan adalah usaha sadar dan terencana untuk mengwujudkan suasana belajar dan proses pembelajaran agar peserta didik secara aktif mengembangkan potensi dirinya untuk memiliki kekuatan spiritual keagamaan, pengendalian diri, kepribadian, kecerdasan, akhlak mulia, serta keterampilan yang diperlukan dirinya, masyarakat, bangsa, dan Negara.

Tujuan dari proses pembelajaran yaitu membekali peserta didik kemampuan, pengetahuan, dan keterampilan agar mampu mengembangkan potensi dirinya. Metode pembelajaraan yang digunakan haruslah tepat terutama dalam pembelajaran Bahasa agar menyenangkan. Melihat fenomena yang terjadi sekarang masih banyak anak-anak, remaja bahkan orang dewasa masih belum trampil dalam berbicara khususnya berbicara menggunakan bahasa bali yang sesuai dengan anggah-ungguhin basa bali. Selain itu, masih banyak yang gengsi berbicara menggunakan bahasa bali, apakah memang kurang paham atau memang minat untuk menggunakan bahasa bali ketika berbicara kurang terkesan kekinian? Melihat kondisi seperti ini, salah satu cara meningkatkan kemampuan berbicara peserta didik yaitu seorang guru tidak hanya menggunakan satu strategi pembelajaran, melainkan menggunakan berbagai strategi pembelajaran yang saling mendorong agar proses belajar mengajar efektif dan efisien.

\subsection{Fokus Penelitian}

Dari konteks penelitian di atas, maka dapat ditarik beberapa pokok penelitian untuk membatasi penjabarannya.

1. Apa itu strategi pembelajaran?

2. Bagaimana strategi guru dalam meningkatkan kemapuan berbicara bahasa bali?

3. Apa factor penghambat dan pendorong siswa dalam berbicara menggunakan bahasa bali?

\subsection{Tujuan Penelitian}

Untuk meningkatkan kemampuan berbicara siswa khususnya bahasa bali dan mengetahui strategi guru dalam proses pembelajaran bahasa bali, serta mengetahui factor penghambat dan pendukungnya.

\subsection{Manfaat Penelitian}

Penelitian ini dapat menambah wawasan seorang guru terkait dengan strategi pembelajaran, bagi siswa dan masyarakat agar lebih mencintai bahasa bali sekaligus bisa mengimplementasikan dalam kehidupan sehari-hari.

\section{METODE PENELITIAN}

Penelitian ini menggunakan metode penelitian kualitatif dengan pendekatan deskriptif dimana peneliti telah menggambarkan strategi guru dalam meningkatkan kemampuan berbicara khususnya bahasa bali. Adapun sumber data dalam penelitian ini yaitu dari berbagai literature seperti buku, artikel, jurnal, internet dan bahan bacaan lainnya sebagai penunjang penelitian ini. Teknik pengumpulan data yang digunakan yaitu dengan membaca berbagai literature dan mengamati kondisi lingkungan sekitar. Teori strategi yang diacu yaitu teori Morrisey. 


\section{PEMBAHASAN}

\subsection{Pengertian Strategi Pembelajaran}

Pada mulanya kata strategi banyak digunakan dalam dunia kemiliteran. Istilah strategi berasal dari bahasa yunani dari kata strategos yang berarti jendral atau panglima. Strategi banyak digunakan dalam berbagai bidang kegiatan untuk mencapai suatu keberhasilan atau tujuan tertentu. Salah satunya yaitu di bidang pendidikan. Strategi yang tepat dalam proses pembelajaran, maka kemungkinan lebih besar untuk mencapai keberhasilan dari tujuan pembelajaran tersebut. Dalam dunia pendidikan, strategi diartikan sebagai a plan, method, or series of actifities designed to achieves a particular educational goal (J.R. David dalam Wina Sanjaya, 2011:126). Sehingga strategi pembelajaran adalah suatu kegiatan perencanaan yang dilaksanakan oleh guru dan siswa agar mencapai tujuan pembelajaran yang efektif dan efisien. Komponen yang harus ada dalam strategi pembelajaran yaitu tujuan, bahan pelajaran, kegiatan belajar mengajar, metode pembelajaran, media pembelajaran, sumber pembelajaran, dan evaluasi pembelajaran.

\subsection{Strategi Guru Dalam Meningkatkan Kemampuan Berbicara Khususnya Bahasa Bali}

Aliran psikologi belajar sangat mempengaruhi strategi pembelajaran ekspositori adalah aliran belajar behavioristik. Aliran ini lebih menekankan pada keterkaitan antara stimulus dan respon. Guru adalah orang yang memiliki kesehatan jasmani rohani yang mampu mendidik seorang anak. Guru adalah pemberi stimulus, kemudian siswa meresponnya, sehingga guru harus mampu memfasilitasi antara stimulus dan respon supaya bisa berlangsung secara efektif dan efisien.

Strategi pembelajaran ekspositori adalah strategi pembelajaran yang menekankan pada penyampaian materi secara verbal. Adapun metode pembelajaran yang cocok dengan strategi pembelajaran ekspositori yaitu metode ceramah, metode demonstrasi, dan metode sosiodarma. Selanjutnya ada, strategi pembelajaran inquiry merupakan rangkaian pembelajaran yang menekankan pada proses berfikir kritis. Strategi ini cocok digunakan dalam melatih kemampuan siswa dalam berbicara menggunakan bahasa bali. Strategi pembelajaran inquiry lebih berorientasi kepada siswa, sehingga siswa memegang peranan yang lebih dominan dalam proses pembelajaran. Metode yang sesuai dengan strategi pembelajaran ini yaitu metode diskusi, pemberian tugas, eksperimen dan Tanya jawab. Melalui metode ini, siswa dapat terlatih untuk berbicara menggunakan bahasa bali.

Strategi guru dalam meningkatkan kemampuan berbicara siswa khususnya memakai bahasa bali yaitu

a. Memakai metode debat aktif. Metode ini bisa dimplementasikan dalam bentuk debat. Contohnya seorang guru memberikan materi mababaosan, kemudian siswa membentuk kelompok, masing-masing kelompok menyiapkan materinya dengan menggunakan bahasa bali, sehingga ketika menyampaikan secara otomatis siswa berbicara dengan bahasa bali.

b. Memakai metode diskusi. Metode ini sangat cocok digunakan dalam melatih kemampuan siswa berbicara bahasa bali karena, ketika siswa berfikir untuk mengemukakan pendapatnya, maka secara otomatis siswa dapat menggunakan kosa kata yang telah dipahaminya.

c. Melalui kegiatan paduan suara. Kelompok paduan suara efektif untuk siswa berlatih berbicara dengan menggunakan bahasa bali, karena ketika siswa menyanyikan sebuah lagu yang menggunakan bahasa bali tentu secara tidak langsung siswa dapat belajar kosa kata bahasa bali.

d. Adapun strategi guru yang lain yang bisa digunakan dalam melatih berbicara menggunakan bahasa bali, sesuai dengan lingkungannya. Seperti ketika kegiatan 
olahraga, bermain catur dan lain sebagainya, yang bisa meningkatkan kemampuan berbicara siswa khususnya bahasa bali.

\subsection{Faktor Penghambat Dan Pendorong Siswa Dalam Berbicara Menggunakan Bahasa Bali}

Kemampuan berbicara pada hakikatnya adalah keterampilan memproduksi arus sistem bunyi artikulasi untuk menyampaikan kehendak, perasaan, pikiran, gagasan dan lain sebagainya. Tujuan berbicara yaitu untuk membangun, menyampaikan ide dalam suatu pembicaraan. Ketika kita berbicara tentunya memiliki tujuan sebagai pemberi informasi, sebagai rekreasi, persuasif, melatih argumentasi dan sebagai indicator dalam pencapaian berbicara.

Adapun factor-faktor yang mempengaruhi kemampuan berbicara seseorang yaitu factor internal dan factor eksternal. Kemampuan berbicara seseorang berbeda-beda ada yang baik adapula yang kurang baik. Itu disebabkan oleh stimulasi yang diterima, lingkungan tempat tinggal, kesehatan jasmani rohani, jenis kelamin, usia, kecerdasan dan lain sebagainya.

Salah satu faktor yang mempengaruhi siswa ketika berbicara menggunakan bahasa bali yaitu lingkungan keluarga. Karena lingkungan keluarga merupakan tempat yang pertama dan utama bagi peserta didik untuk belajar. Sehingga apabila dari lingkungan keluarga tidak mau mengajarkan anaknya berbicara menggunakan bahasa bali yang sesuai dengan anggahungguhing basa bali, maka akan sulit anak tersebut mampu berbicara yang sopan dan santun. Apalagi orang tua hanya mengajarkan anaknya bahasa asing saja, tanpa mengajarkan bahasa ibu kepada anaknya, maka itu akan sulit juga untuk meningkatkan kemampuan menambah kosa kata dalam bahasa bali. Apabila itu terjadi maka, ketika di sekolah guru akan kewalahan dalam mendidik siswa tersebut supaya terampil dalam berbicara menggunakan bahasa bali.

Perkembangan teknologi juga mempengaruhi kemampuan siswa dalam berbicara menggunakan bahasa bali, karena ketika seorang anak mendengar kata-kata gaul melalui telepon genggamnya maka si anak secara tidak langsung akan menirunya hal ini cenderung membuat si anak kurang memperhatikan bahasa bali.

Adapun factor pendukung siswa supaya lebih meningkatkan kemampuan berbicara menggunakan bahasa bali, bisa melalui lingkungan keluarga, hal ini jika lingkungan keluarga mau ikut melestarikan budaya bali yang berupa bahasa bali. Selain itu motivasi dari seorang guru di sekolah sangat membantu meningkatkan kemampuan berbicara menggunakan bahasa bali. Kerabat di lingkungan tempat tinggal siswa juga bisa membantu mengajarkan berbicara menggunakan bahasa bali yang sopan dan santun, berdasarkan anggah-ungguhing basa bali.

\section{KESIMPULAN}

Strategi pembelajaran adalah salah satu upaya untuk meningkatkan kemampuan belajar siswa. Penggunaan strategi pembelajaran yang tepat, memungkinkan siswa lebih trampil dalam berbicara menggunakan bahasa bali. Peran guru sangat penting dalam rangka memotivasi peserta didiknya agar trampil berbicara menggunakan bahasa bali. Adapun factor internal dan eksternal yang mempengaruhi tingkat keterampilan siswa berbicara berbahasa bali. Penulis menyadari tulisan ini masih jauh dari kata sempurna, maka dari itu kritik konstruktif dari pembaca sangat penulis harapkan. Semoga tulisan ini berguna bagi diri penulis dan masyarakat.

\section{DAFTAR PUSTAKA}

Attamimi, Nurul Fakihatul Jannah. 2017. Strategi Guru Dalam Meningkatkan Kemampuan

Berbicara Siswa Pada Mata Pelajaran Bahasa Jawa Di Mi Muhammadiyah 19

Sidokumpul Paciran Lamongan. Skripsi. Malang.

Sanjaya, W. (2011). Strategi Pembelajaran Berorientasi Standar Proses Pendidikan. Jakarta:

Kencana. 
Sugiyono. (2011). Metode Penelitian Kualitatif, Kualitatif Dan R\&D. Bandung: Alfabeta.

Sutikno, M. S. (2013). Belajar Dan Pembelajaran "Upaya Keatif Dalam Mengwujudkan Pembelajaran Yang Berhasil". Lombok: Holistica. 